\title{
"The interaction between governance, social responsibility, and territorial attractiveness: an application of "the structural equation modeling approach"”,
}

\begin{tabular}{|c|c|}
\hline \multirow{3}{*}{ AUTHORS } & \\
\hline & Lorena Caridad (D) https://orcid.org/0000-0002-3406-9917 \\
\hline & Nuria Ceular Villamandos \\
\hline ARTICLE INFO & $\begin{array}{l}\text { Hosn el Woujoud Bousselmi, Lorena Caridad and Nuria Ceular Villamandos } \\
\text { (2018). The interaction between governance, social responsibility, and territorial } \\
\text { attractiveness: an application of "the structural equation modeling approach". } \\
\text { Investment Management and Financial Innovations, 15(4), 239-257. } \\
\text { doi:10.21511/imfi.15(4).2018.20 }\end{array}$ \\
\hline DOI & http://dx.doi.org/10.21511/imfi.15(4).2018.20 \\
\hline RELEASED ON & Thursday, 29 November 2018 \\
\hline RECEIVED ON & Sunday, 16 September 2018 \\
\hline \multirow[t]{2}{*}{ ACCEPTED ON } & Thursday, 25 October 2018 \\
\hline & $(\mathrm{ccc}) \mathrm{EY}$ \\
\hline LICENSE & $\begin{array}{l}\text { This work is licensed under a Creative Commons Attribution } 4.0 \text { International } \\
\text { License }\end{array}$ \\
\hline JOURNAL & "Investment Management and Financial Innovations" \\
\hline ISSN PRINT & $1810-4967$ \\
\hline ISSN ONLINE & $1812-9358$ \\
\hline PUBLISHER & LLC "Consulting Publishing Company "Business Perspectives" \\
\hline FOUNDER & LLC "Consulting Publishing Company "Business Perspectives" \\
\hline
\end{tabular}

NUMBER OF REFERENCES

76

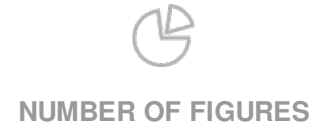

5
NUMBER OF TABLES

14

(C) The author(s) 2021. This publication is an open access article. 


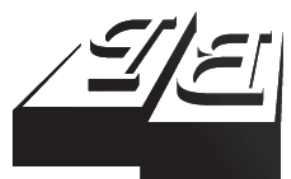

BUSINESS PERSPECTIVES

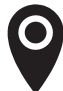

LLC "CPC "Business Perspectives" Hryhorii Skovoroda lane, 10, Sumy, 40022, Ukraine

www.businessperspectives.org

Received on: $16^{\text {th }}$ of September, 2018 Accepted on: $25^{\text {th }}$ of October, 2018

(C) Hosn el Woujoud Bousselmi, Lorena Caridad, Nuria Ceular Villamandos, 2018

Hosn el Woujoud Bousselmi, Ph.D. Student, visiting from Tunis University, University of Córdoba, Spain.

Lorena Caridad, Economist, Marypaz Co., Spain.

Nuria Ceular Villamandos, Prof. Head of Department, Department of Econometrics and Operational Research, University of Córdoba Spain.

\section{() (i)}

This is an Open Access article, distributed under the terms of the Creative Commons Attribution 4.0 International license, which permits unrestricted re-use, distribution, and reproduction in any medium, provided the original work is properly cited.

Hosn el Woujoud Bousselmi (Spain), Lorena Caridad (Spain),

Nuria Ceular Villamandos (Spain)

THE INTERACTION BETWEEN

GOVERNANCE, SOCIAL RESPONSIBILITY, AND TERRITORIAL ATTRACTIVENESS: AN APPLICATION OF "THE STRUCTURAL EQUATION MODELING APPROACH"

\begin{abstract}
The purpose of this article is to present and test a conceptual framework that describes how the government's commitment in improving corporate social responsibility (CSR) practices promotes the attraction of foreign direct investment (FDI) in Tunisia. As such, this conceptual framework inspires the existence of an interaction between the improvement of CSR practices by public policies (PP), and the attraction of FDI. In this regard, this study applied structural equation modeling (SEM) to empirically test this proposed model. It finds that the Tunisian government is valuing CSR and considering it as an investment. It presents examples of instruments, PP and tools that encourage to adopt CSR practices, thus, enhancing the attraction of FDI, which will have a positive impact on the growth of the country in terms of wealth creation, jobs and poverty reduction.
\end{abstract}

\section{Keywords}

JEL Classification

\section{INTRODUCTION}

Tunisia is evolving in a context of profound changes affecting the political, social and economic system. The pressure of these changes has grown at the international level with the opening of the country to its external environment and the effect of globalization. To ensure its survival, any company is condemned to question itself every day by identifying the key factors of success. It is led to look for the best strategy to adopt, and to maintain its competitive advantage.

According to the study carried out by the Deutsche Gesellschaft für Internationale Zusammenarbeit in 2010 entitled "La Responsabilité sociétale des enterprises en Tunisie" (GIZ, 2010), several objectives were achieved in Tunisia in the field of CSR practices before January 14 , 2011. Moreover, since 2005, this country adopted international human rights conventions and encouraged the implementation of the UN Global Compact (United Nations Global Compact). According to the same study, in a post-revolutionary context, the country is experiencing changes at the political, economic and social levels. That is why, the activities in the field of CSR, which have been developed by the support of international cooperation in Tunisia, have not been well structured. According to The United Nations Industrial Development Organization (UNIDO), these activities suffer a relaxation of compa- 
nies in relation to their commitments and CSR strategy (UNIDO, 2016). As a result, the government, the economic and social actors are led to integrate these changes into their policies and strategies in order to open new perspectives for CSR.

On the other hand, the revolution revealed the misdeeds of unequally distributed growth and its negative effects on corporate sustainability and social cohesion (World Bank, 2015). Thus, it is a question of valorizing a development strategy, which aims to integrate the economic, social and environmental dimensions of the CSR favoring the consideration of the durability of the companies and concerns of the population, which makes it possible to identify key players in CSR. The development of a policy based on clear objectives and a long-term vision for CSR is therefore necessary. Such a policy aims to improve the business environment and increase the competitiveness of enterprises by promoting the culture of work (GIZ, 2010).

In this uncertain context, public authorities are expected to regain investor confidence by developing basic infrastructure, administrative services and support structures (El Malki, 2010; Sfar \& Mtar, 2015). This will restore the stability of the business climate in Tunisia. Indeed, it is impossible to recover the economy while the business climate suffers from several failures. The awareness of the entire political class and all components of civil society is necessary to boost investment in Tunisia, which can unlock the economic machine. In this respect, sustainable development must be considered as a priority for the government. The establishment of coherent orientations and strategies over the medium and long term will create an attractive business environment. In fact, the aim of this study is to highlight the role of the Tunisian government in improving CSR practices in order to facilitate the entry of foreign direct investment (FDI).

\section{LITERATURE REVIEW}

The territorial attractiveness (TA) represents the first basic concept of this study. It is defined as the ability of the territory to attract financial, technological and human resources and the ability of the latter to maintain investments already located in this territory (Hatem, 2004; Le Roy \& Ottaviani, 2011; Elhasbi et al., 2015). This concept has always been studied while taking into consideration the concept of "territorial competitiveness". This last reflects the ability of a company or nation to improve its position in the face of competition from other economic units. It is therefore an effective way of improving social well-being. The two notions of attractiveness and competitiveness are therefore two factors essential to the development of nations (Hatem, 2004; Le Roy \& Ottaviani, 2011).

The notion of TA has led to the consideration of a new management method, which is reflected in the concept of "intelligent economy". It is a knowhow composed of methods and tools for monitoring, and public policies (PP) allowing the growth of power through economic security strategies and actions of collective control of strategic information.
In this study, Michalet's (1999) approach was used to determine the factors of TA. Indeed, it is a global and clear approach allowing to synthesize the various determinants of FDI that have been identified not only in theoretical studies, but also in the empirical studies on FDI factors in developing countries. As a result, Michalet (1999) distinguished two types of TA factors, namely the fundamental factors of attractiveness and the conditions necessary for attractiveness. These factors are illustrated in Figure 1.

The corporate social responsibility (CSR) is the second basic concept of this study. This concept has been apprehended in many ways by many authors and a multitude of organizations according to distinct theoretical and managerial approaches; but they have not reached a compromise on the definition of this concept. These authors and organizations have brought to light the ideology of "Triple Bottom Line", which will reflect the fundamentals of CSR. It's about considering not only the financial result, but also the social and environmental balance sheet of the company (Igalens et al., 2002; Capron \& Quairel-Lanoizelée, 2004; Pesqueux, 2009). 


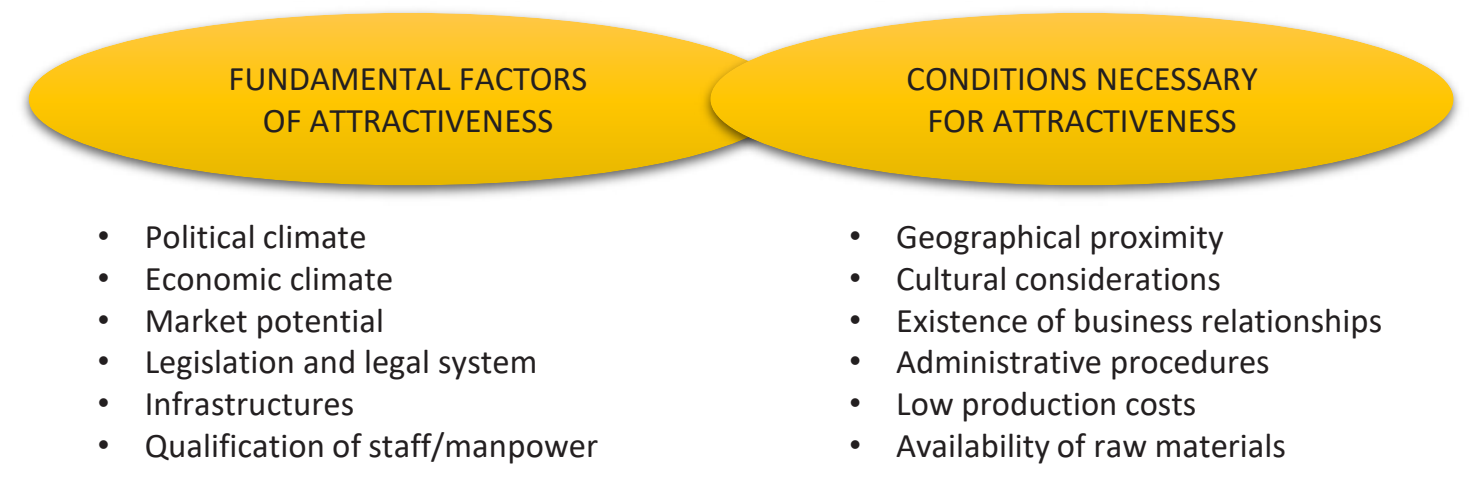

Figure 1. Territorial attractiveness factors according to Michalet (1999)

In an international context, multinational companies must first respond to global demands. They must comply with regulations and face local pressures to adapt products to the standards and requirements of each country.

The literature on CSR in an international context has addressed the determinants of social approaches not only at the level of the company, but also at the level of the subsidiary. It identifies economic, institutional, organizational and managerial variables. On the one hand, Campbell (2007) considers that the regulation of the host country is an important institutional determinant that promotes social practices. For his part, Borchani Maktouf (2008) points out that the legislation, the social norms, the stakeholder's expections and the pressures of interest groups are the main determinants that improve CSR practices. This author shows that the social re- sponsibility of foreign subsidiaries that are established in France is influenced by the social norms that govern the guiding principles of the multinationals, by the legislation of Europe and finally by the expectations of the stakeholders. On the other hand, according to Borchani (2008), the business line of subsidiary and the subsidiary's size, are essential organizational variables that determine a societal approach. McWilliams and Siegel (2001) concluded that the CSR depends on research and development and the extent of product differentiation. Finally, Cournac (2013) highlighted other managerial variables, namely the manager's commitment and the stakeholder's expectation feedback. These social approaches of multinational companies seem to be the result of the influence of institutional pressures on the country of origin and the host country. These variables are presented in Figure 2.

Source: Personal elaboration according to the foundations of Borchani (2008).

\section{INSTITUTIONAL VARIABLES}
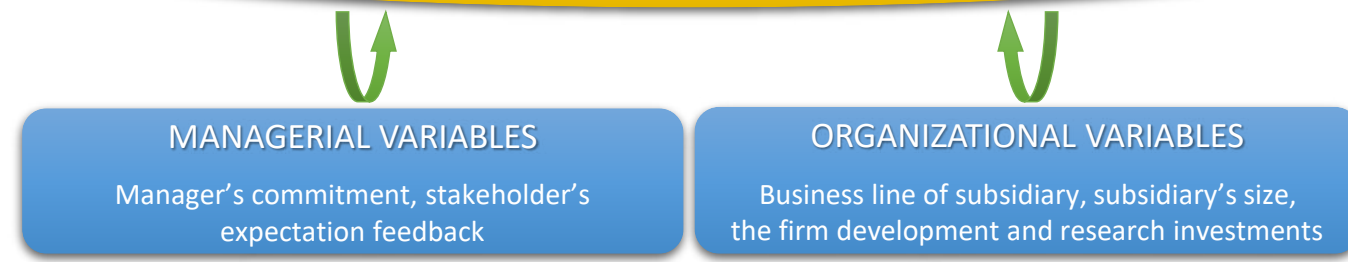

Figure 2. Determinants of c CSR practices case of multinational companies. Personal elaboration according to the foundations of Borchani (2008) 
The last basic concept is that of public policies (PP) that will improve CSR practices to stimulate an investment climate favorable for the entry of FDI. In this context, the concept of business climate has been highlighted in this study, because it represents the set of policies, instruments and tools that can improve these practices (Pleskovic \& Stern, 2002).

In an environment characterized by divergent interests, the subsidiary is unable to define and prioritize problems. The host government will thus play the role of guarantor of the respect of the rights (Kubler, 2001). First, the latter must fight against the violation of human rights and property. It has to put in place a clear legislative framework, and to ensure the flexibility of the labor market, because they will be among the factors, which improve the social practices of the subsidiary located on the host territory. But, it's not enough to have laws only on paper; they must also be applied in the field in the most efficient way. On the other hand, the establishment of partnership relations with foreign companies through CSR practices, such as the customer's requirement to a local supplier of a quality standard, also seems a useful option, which will allow to develop a strong local economic framework. In order to promote these practices, it seems useful to increase financial incentives to develop human capital. Thus, it is necessary to financially consolidate research and development and promote accreditation systems and certification, in order to improve the quality of education in universities. It is also about putting in place programs that help employees integrate the notion of change into their workplace and protect them, such as social protection programs.

In a globalized world, knowledge and information have become strategic assets of prime importance. The introduction of innovative information systems capable of managing environmental uncertainty will be a good alternative to facilitate the flow of strategic information between different actors of the territory (public authorities, companies, civil society, etc.). Monitoring, sharing and dissemination of the environment must be appreciated. This raises the question of the use of new information and communication technologies. The good quality of infrastructures will therefore be a fundamental determinant of TA (Michalet, 1999). All these policies, tools and practices will positively influence social cohesion as a key lever that encourages foreign investors to settle in a given territory (Ben Slymen, 2014). They will be consolidated while adopting a participatory ap-

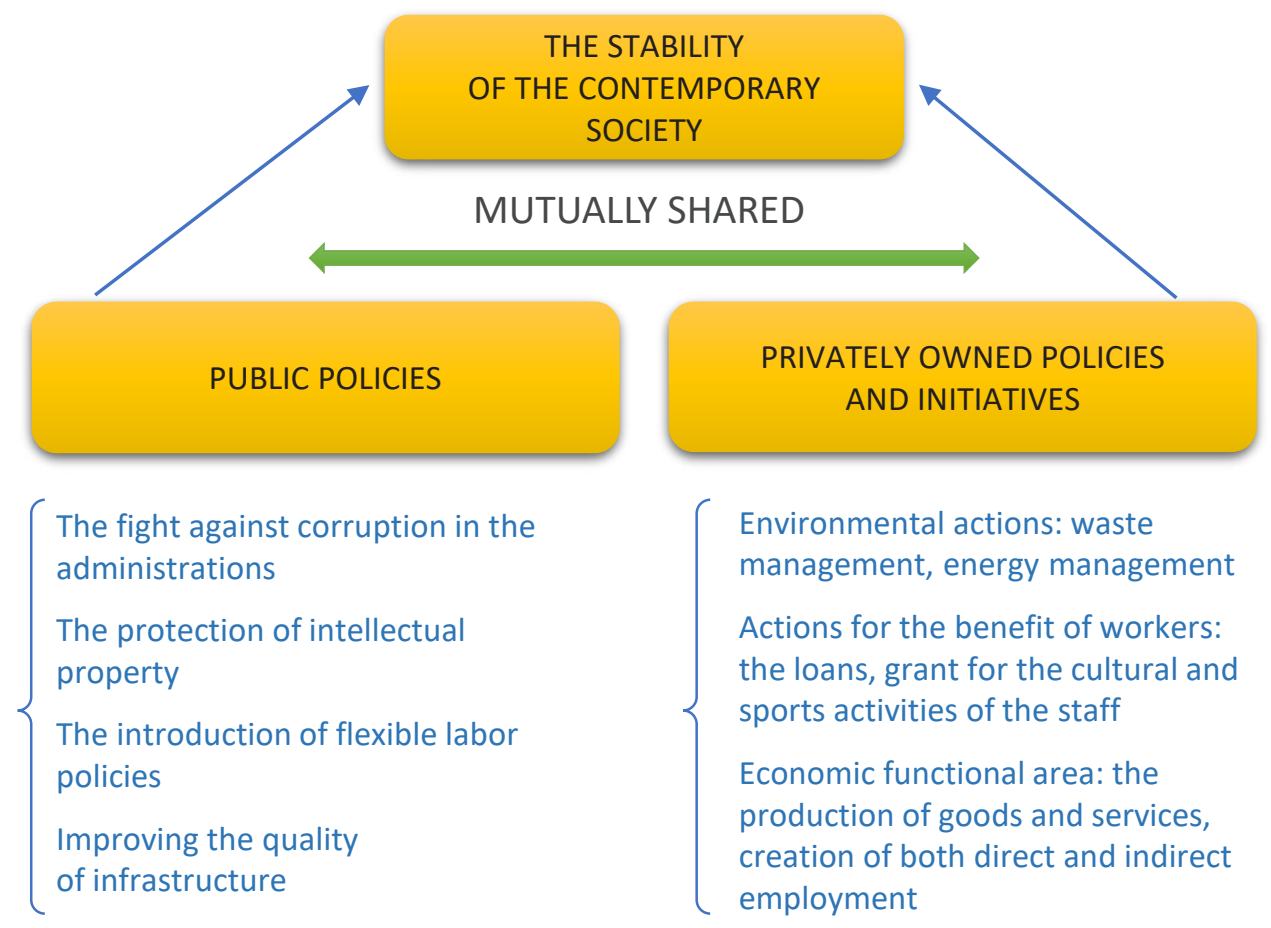

Figure 3. Personal elaboration according to the foundations of El Malki (2010), World Bank (2005) and Navas and Guerras (2018) 
proach involving these different actors (Martinet \& Payaud, 2008; Ben Slymen, 2014). In this respect, Michael (1999) considers that the existence of an environment conducive to innovation attracts the attention of foreign investors. The latter would be characterized by the existence of efficient public laboratories, a skilled workforce and specialized infrastructures. It is a question of considering the conditions of implementation of a collective strategy of sustainable development.

Nevertheless, the attraction of FDI by the promotion of CSR practices, is not merely assured on (PP), but it should be also bounded on privatelyowned policies and initiatives. This interface of operation and procedures between public and private capabilities is established in Figure 3.

\section{HYPOTHESES DEVELOPMENT}

The purpose of this study is to examine the impact of the government's commitment (PP), in improving CSR practices, on the attraction of FDI.

\subsection{Relation between PP and the attraction of FDI}

The contribution of FDI to countries' economic growth has led governments in developing countries to develop PP that attract FDI (Pleskovic \& Stern, 2002; World Bank, 2005; Karray \& Toumi, 2007). It is therefore a question of fostering an investment climate generating opportunities that push the company to invest in human and technological capital. This investment climate is affected by a number of PP (Asaftei et al., 2008; Carlin et al., 2006), which will have a positive impact on the country's growth in terms of wealth creation, employment and poverty reduction (Pleskovic \& Stern, 2002; El Malki, 2010; Ouguenoune, 2014). Indeed, political stability attracts the attention of foreign investors (Muchielli, 1998; Karray \& Sofien, 2007; Sfar \& Mtar, 2015). The World Bank (2005) argues that the protection of industrial and intellectual property rights improves the political stability of countries. It is a form that reassures investors of the future of their investments (Drabek \& Payne, 2001; Boualam, 2008). On the other hand, Michalet (1999) considers that large companies are looking for a network of successful local business with which partnerships can be built. In this regard, the host government needs to develop PP, such as qualification of the workforce. Several studies (Lucas, 1988; Borensztein et al., 1998; Goumrhar, 2017) show that the development of human capital is a fundamental element that strengthens the attraction of FDI. Leriche et al. (2006) explained that the promotion of the notion of creativity must also be considered (artists, creators, designers, etc.). Host governments must therefore create favorable conditions for the emergence of established partnerships between foreign companies located in the territory and other actors (research centers, public authorities, local businesses, universities, etc.). The aim is to provide new knowledge and skills (Cournac, 2013; Benhamou et al., 2016).

In this globalized world, foreign investors attach great importance to the quality of the infrastructure, especially the efficiency of the telecommunications and transport network (Wei, 2000). With the rise of high-tech activities and their evolution, foreign companies want to exploit the specificities of each national innovation system (Michalet, 1999). From these theoretical foundations, the first hypothesis follows, according to which:

\section{H1: PP have a direct impact on the TA.}

\subsection{Relation between PP and CSR practices}

Subsidiaries located in a host territory must face the different problems in a context characterized by divergent interests. This is why, host governments are required to establish a minimum list of organizations to be consulted by the companies that will be responsible for dealing with certain subjects in this area (Houle, 2012; Tang, 2018). It is an acceptable framework that can put in place incentives for socially responsible investment. The aim is to promote PP, such as the fight against corruption (Boualam, 2008; El Malki, 2010; Ouguenoune, 2014). Securing the rights of the parties involved in a financial transaction will increase the willingness of companies to invest (Demurguc-Kunt \& Maksimovic, 1998, Jappelli \& Pagano, 1999; Erb et al., 2000; Fafchamps, 2004; Tang et al., 2018). 
Alesina et al. (2003) studied the difficulties of bureaucracy and customs administration, such as corruption and delays resulting in additional costs. Wei (2000) shows that the level of corruption is strongly and negatively correlated with (FDI). The modernization of customs procedures will be the appropriate solution to deal with these problems, which contributes to improving the efficiency of customs administrations (El Malki, 2010). From these theoretical foundations, the second hypothesis follows, according to which:

\section{H2: $\quad$ PP have a significant positive impact} on the CSR practices of the subsidiary.

\subsection{Impact of the improvement of CSR practices on the TA}

Cournac (2013) considers that the territory is a place of education and incentive to CSR initiatives. In this respect, innovation will play a key role in economic growth. It refers to the different aspects of the qualifications of the workforce. It is a socially accepted invention and it can be technological, economic, and social (Pumain et al., 2007).

Research by Colletis and Pecqueur (2005) has highlighted the notion of specific resources. According to these authors, this notion refers to skills that are capable of producing knowledge, which cannot be transferred. Thus, the permanence of the territorial attractiveness is important when the territory has resources and specific assets (Colletis \& Pecqueur, 2005). For example, product labeling will be the appropriate approach to meet this new demand (Pecqueur, 2002; Perret, 2011).

Benhamou et al. (2016) specified that the partnership relationship that can be established between principals and suppliers through certain CSR practices is a vector of economic efficiency. By working in a network, these practices will be based on mutual respect of shared values between stakeholders. According to these authors, these practices will be a necessary factor in the attractiveness of the territories (Benhamou et al., 2016).

Research by Martinet and Payaud (2010) showed that financial incentives led to the development of a collective strategy for sustainable development. These incentives are granted in the framework of a con- tractualization with the state and the region. Thus, the territory is a place of regulation, awareness and incentive for CSR initiatives.

On the other hand, the concept of CSR, applied to restructuring has developed in a context of industrial change, where restructuring has become essential to strengthen the competitiveness of companies (Cournac, 2013). These restructurings can lead to employment, social and environmental problems. It is in this context that Igalens et al. (2002) emphasized the concept of "socially responsible restructuring". The responsibility towards the territory must therefore contribute to minimizing the destabilization of the framework of companies and employment areas. The government must prepare employees for the realities of the market. It must accompany them in a logic of economic development and maintenance of employment (Beaujolin, 2008; El Malki, 2010; Cournac, 2013; Ouguenoune, 2014; Tang et al., 2018).

Several studies such as La Porta et al. (1999), Bronisz and Heijman (2009) have shown that regions capable of attracting businesses are the same as those with the highest levels of social capital.

Bertacchini (2004) and Ben Slymen (2014) focused on the concept of "economic intelligence". These are essentially environmental monitoring and information-sharing practices. These practices will contribute to the development of innovative solutions that can effectively address environmental uncertainties. Following a mastery of the environment, they will allow public or private institutions to have actors capable of anticipating (Bertacchini, 2004; Ben Slymen, 2014). These mechanisms will be consolidated by promoting a participatory approach that will highlight the diagnoses of real needs, the intangible heritage and attract new investors (Bertacchini, 2010; Ben Slymen, 2014). From these theoretical foundations, the third hypothesis follows, according to which:

\section{H3: The improvement of CSR practices through the PP has a significant positive impact on the attraction of FDI.}

Based on the literature review and hypotheses of the study, the conceptual framework was proposed as presented in Figure 4. The proposed conceptual model is composed of three variables: territorial attractiveness (TA), corporate social responsibility 


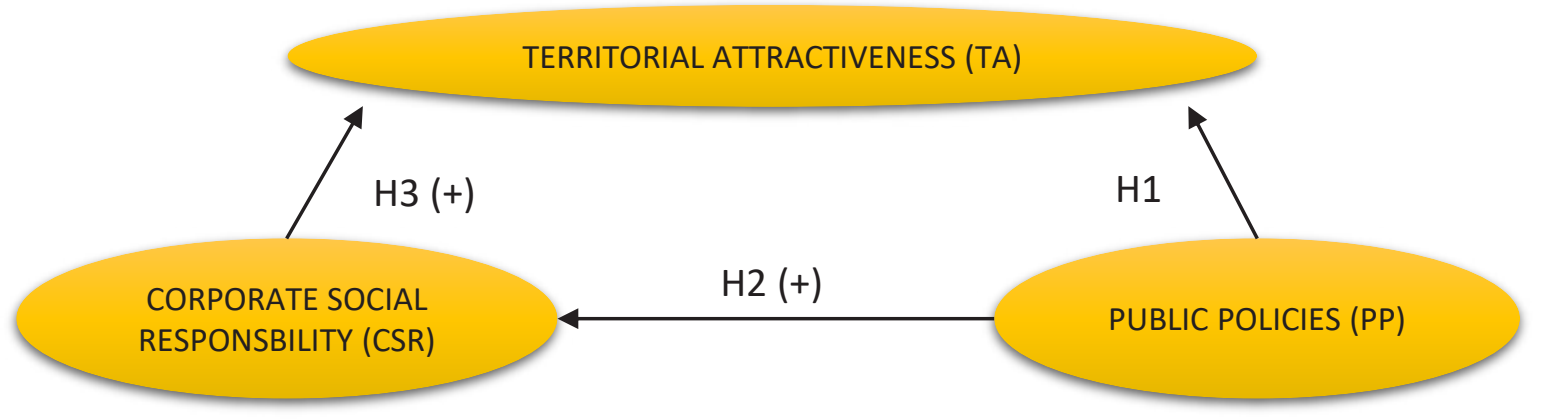

Figure 4. Proposed conceptual framework

(CSR) and public policies (PP). It illustrates how the government's commitment in improving CSR practices can promote the attraction of FDI.

\section{METHODS}

In management science, it is possible to distinguish three epistemological paradigms, namely positivism, interpretativism, and constructivism (Thietart, 2003). These paradigms present three different ways of defining the knowledge and its value. This research work aims to study how the government's commitment in improving CSR practices can strengthen the attraction of FDI in Tunisia. Thus, given the object and the problematics of research, positivist epistemological positioning is perfectly suited to our research question. Indeed, it brings us the indispensable confrontation of the hypotheses formulated with the reality.

Based on the nature of the question and the objectives, as well as the characteristics of this research, a quantitative research method is adopted. According to Creswell (2011), quantitative research is often referred to as a search for hypotheses testing. A questionnaire targeted at a sample of fully exporting companies located in Tunisia for a few years. In this context, Table 1 presents these companies while Table 2 describes the profile of respondents.

Table 1. Companies contributing to the CSR located in Tunisia

\begin{tabular}{c|c:c|c}
\hline $\begin{array}{c}\text { Activity } \\
\text { area }\end{array}$ & Product & $\begin{array}{c}\text { Export } \\
\text { percentage } \\
\text { (FDI) }\end{array}$ & $\begin{array}{c}\text { Number } \\
\text { of companies }\end{array}$ \\
\hline Industry & Clothes & $\begin{array}{c}\text { Totally exporting } \\
\text { company }\end{array}$ & 65 \\
\hdashline Industry $_{n}$ & $\begin{array}{c}\text { Waste } \\
\text { recycling }\end{array}$ & $\begin{array}{c}\text { Partially exporting } \\
\text { company }\end{array}$ & 13 \\
\hline
\end{tabular}

Table 2. Profile of respondents

Source: Authors' calculation.

\begin{tabular}{l|c:c}
\hline Gender distribution & Frequency & \% \\
\hline Women & 6 & 7.7 \\
\hline Man & 72 & 92.3 \\
\hline Distribution by age & - & - \\
\hline Less than 35 years & 19 & 24.4 \\
\hline Between 35 and 45 years & 22 & 28.2 \\
\hline More than 45 years & 37 & 47.4 \\
\hline Status of respondents & - & - \\
\hline Investors & 26 & 33.3 \\
\hline General Director & 18 & 23.1 \\
\hline Manager & 30 & 38.5 \\
\hline Human Resources & 4 & 5.1 \\
Manager & - & - \\
\hline Nationality & 30 & 39 \\
\hdashline French & 26 & 33 \\
\hline Italian & 22 & 28 \\
\hline Spanish & &
\end{tabular}

\section{RESULTS}

\subsection{Exploratory study}

To validate the research hypotheses, a quantitative analysis was carried out: a questionnaire targeted on a sample of 78 managers of FDI located in Tunisia for a few years. In addition, a scientific study assumes a systemic method of collecting the data necessary for the verification of hypotheses (Vilatte, 2007). The questionnaire thus constitutes the material support for the data collection during the survey. It was developed on the basis of certain variables that seek to assess how the government's commitment in improving CSR practices attracts FDI. Responses were collected from foreign affiliates in Tunisia; SPSS software is used for statistical analysis, descriptive analysis, and structural model to investigate our hypotheses. 


\subsubsection{Descriptive analysis}

A cross sorting is realized besides the basic description of the variable and several associations of Chi-square test are performed. The results show that there is, on the one hand, a significant relationship between PP and TA and, on the other hand, a significant dependency relationship between the improvement of CSR practices by PP and the TA. The corresponding $p$-values are less than $10 \%$ in every case and most of them are less than $1 \%$.

\subsubsection{Analysis of the reliability of measurement scales}

Reliability or fidelity means "the degree of stability of a measurement for an indefinite time, regardless of the participants". Thus, a measure will only be reliable if it is understood and interpreted identically by all participants (cited by Rouissi, 2016).

Reliability analysis is used to study the properties of measurement scales and the elements that make them up. It determines to what extent the elements of a questionnaire are related to each other and to provides a general index of the consistency or internal coherence of a scale as a whole. There are several criteria for measuring the reliability. But, the most recommended measure for assessing the internal consistency of a set of items is given by Cronbach's alpha coefficient (cited by Rouissi, 2016). Nunnally and Bernstein (1978) recommend it for assessing the reliability of items. Thus, for an exploratory study, a threshold of 0.6 for $\alpha$ is sufficient, according to the latter. In general, a threshold of 0.7 is considered a minimum for deciding on the reliability of a construct. Evrard et al. (1993) consider that in the case of exploratory studies,

Table 3. Cronbach's alpha values the value of Cronbach's alpha is acceptable when it is between 0.6 and 0.8 .

Table 3 shows the internal coherence between the items of each concept.

\subsubsection{Principal component analysis (PCA) of concepts}

A dimensionality study must be considered in order to verify the number of dimensions to be retained. Table 4 presents the purification of the scales of measurements, which consists of checking the quality of each item in order to retain that the items, which have factorial contributions higher than 0.5 , and to eliminate the irrelevant items. In this case, a PCA is performed. The verification of the variance percentage explained by the analysis is essential (cited by Mkaouar, 2016).

For the three concepts of our analysis, the values of the KMO exceed the critical threshold of 0.6. The Bartlett sphericity tests are statistically significant with p-values below 0.001 . The analysis of the variance shows that more than $60 \%$ of the total variance is explained by the items of concepts. The factorial analyses carried out on all the scales of measurement show satisfactory values of the KMO indices and Bartlett sphericity test. Thus, the data is factorizable. Finally, the concept of TA is composed of four axes, the second concept CSR also includes four axes and the PP concept has five axes.

\subsection{Structural model}

The partial least squares (PLS) method is used while considering the sample size. Moreover, the use of PLS has several interests. The assumptions

\begin{tabular}{|c|c|c|}
\hline Concept & Dimensions & Cronbach's alpha \\
\hline \multirow{2}{*}{ Territorial attractiveness (TA) } & Fundamental factors of TA & 0.815 \\
\hline & Advantages of the location of investment & 0.828 \\
\hline \multirow{4}{*}{ Corporate social responsibility (CSR) } & Determinants of the social strategy of the subsidiary & 0.860 \\
\hline & Stakeholders of the subsidiary & 0.929 \\
\hline & Principles of CSR & 0.846 \\
\hline & Obstacles to overcome in the implementation of a CSR policy & 0.843 \\
\hline \multirow{3}{*}{$\begin{array}{l}\text { Improvement of CSR practices by PP to } \\
\text { attract FDI (PP) }\end{array}$} & Investment climate in Tunisia & 0.883 \\
\hline & Barriers that prevent investors from investing in Tunisia & 0.677 \\
\hline & $\begin{array}{l}\text { Recommendations proposed to the state in order to make } \\
\text { Tunisia more attractive }\end{array}$ & 0.612 \\
\hline
\end{tabular}


Table 4. Concept's PCA

\begin{tabular}{|c|c|c|c|c|c|}
\hline Concept & Dimensions & $\begin{array}{l}\text { Bartlett } \\
\text { sphericity } \\
\text { test }\end{array}$ & $\begin{array}{l}\mathrm{KMO} \\
\text { index }\end{array}$ & $\begin{array}{l}\text { Explained } \\
\text { variance }\end{array}$ & $\begin{array}{l}\text { Number } \\
\text { of axes } \\
\text { retained }\end{array}$ \\
\hline \multirow{2}{*}{$\begin{array}{l}\text { Territorial attractiveness } \\
\text { (TA) }\end{array}$} & Fundamental factors of TA & $\begin{array}{c}216,346 \\
\text { p-value }(0.000)\end{array}$ & 0.74 & 61.415 & 2 \\
\hline & $\begin{array}{l}\text { Advantages of the location of } \\
\text { investment }\end{array}$ & $\begin{array}{c}304,125 \\
p \text {-value }(0.000)\end{array}$ & 0.69 & 86.763 & 2 \\
\hline \multirow{4}{*}{$\begin{array}{l}\text { Corporate social } \\
\text { responsibility (CSR) }\end{array}$} & $\begin{array}{l}\text { Determinants of the social strategy of } \\
\text { the subsidiary }\end{array}$ & $\begin{array}{c}357,634 \\
\text {--value }(0.000)\end{array}$ & 0.73 & 65.584 & 1 \\
\hline & Stakeholders of the subsidiary & $\begin{array}{c}603,251 \\
\text { p-value }(0.000)\end{array}$ & 0.81 & 74.065 & 1 \\
\hline & Principles of CSR practices & $\begin{array}{c}552,262 \\
p \text {-value }(0.000)\end{array}$ & 0.71 & 72.028 & 1 \\
\hline & $\begin{array}{l}\text { Obstacles to overcome in the } \\
\text { implementation of CSR policy }\end{array}$ & $\begin{array}{c}323,864 \\
p \text {-value }(0.000)\end{array}$ & 0.75 & 70.157 & 1 \\
\hline \multirow{3}{*}{$\begin{array}{l}\text { Improvement of CSR } \\
\text { practices by PP to attract } \\
\text { FDI (PP) }\end{array}$} & Investment climate in Tunisia & $\begin{array}{c}295,365 \\
\text { p-value }(0.000)\end{array}$ & 0.72 & 70.017 & 1 \\
\hline & $\begin{array}{l}\text { Barriers that prevent investors from } \\
\text { investing in Tunisia }\end{array}$ & $\begin{array}{c}190,042 \\
p \text {-value }(0.000)\end{array}$ & 0.63 & 76.973 & 2 \\
\hline & $\begin{array}{l}\text { Recommendations proposed to the } \\
\text { state in order to make Tunisia more } \\
\text { attractive }\end{array}$ & $\begin{array}{c}42,407 \\
\text { p-value }(0.000)\end{array}$ & 0.58 & 56.517 & 2 \\
\hline
\end{tabular}

of this method are flexible, the conditions of normality of the variables and residues are not necessary, the size of the sample does not condition the model and there are no particular constraints concerning the independence of the observations.

\subsubsection{Evaluation of the conceptual model}

Table 5 presents the convergent validity of the external model, which is evaluated using the model coefficients loadings. These coefficients have acceptable values in the majority of cases concerning the links between the concepts and their measurements.

Table 5. Loadings table

\begin{tabular}{l|c|c|c}
\hline $\begin{array}{c}\text { Concepts } \\
\text { measurement }\end{array}$ & APP (PP) & AT (TA) & RSE (CSR) \\
\hline Climaffai & 0.874 & 0.924 & 0.795 \\
\hline Obstinv 1 & 0.922 & 0.835 & 0.920 \\
\hline Obstunv 2 & -0.401 & -0.119 & -0.216 \\
\hline Recomd 1 & 0.805 & 0.589 & 0.612 \\
\hdashline Recomd 2 & 0.120 & 0.032 & 0.216 \\
\hline F fond 1 & 0.849 & 0.965 & 0.896 \\
\hline F fond 2 & 0.100 & 0.080 & 0.106 \\
\hdashline Av 1 & 0.936 & 0.971 & 0.914 \\
\hline Av 2 & -0.068 & 0.535 & 0.051 \\
\hline Rssoc & 0.886 & 0.893 & 0.947 \\
\hdashline Partpre & 0.935 & 0.957 & 0.976 \\
\hdashline PrinRssoc & 0.803 & 0.774 & 0.921 \\
\hdashline Obstacles & 0.928 & 0.939 & 0.974 \\
\hline
\end{tabular}

Table 6 presents the discriminant validity. It is tested in order to ensure that this is an appropri- ate specification of the relationships that specify the model. So, the ability of a construct is checked to share more variance with its measures than it shares with others built in the same model. It also means that constructs (concepts) and their measures (manifest variables) cannot be discriminated and that it is therefore inappropriate to view them as distinct and separate theoretical entities.

Table 6. Discriminant validity

\begin{tabular}{l|c:c:c:c}
\hline \multicolumn{1}{c}{ Concepts } & $\begin{array}{c}\text { APP } \\
\text { (PP) }\end{array}$ & $\begin{array}{c}\text { RSE } \\
\text { (CSR) }\end{array}$ & AT (TA) & $\begin{array}{c}\text { Average } \\
\text { communalities } \\
\text { (AVE) }\end{array}$ \\
\hline APP (PP) & 1 & 0.870 & 0.856 & 0.455 \\
\hdashline RSE (CSR) & 0.870 & 1 & 0.878 & 0.911 \\
\hline AT (TA) & 0.856 & 0.878 & 1 & 0.470 \\
\hdashline $\begin{array}{l}\text { Average } \\
\text { communalities } \\
\text { (AVE) }\end{array}$ & 0.455 & 0.911 & 0.470 & 1 \\
\hline
\end{tabular}

The average variances (also called mean commons) of each concept exceed the loadings coefficients. This means that each concept shares more variance with its measures than other concepts which gives the possibility of discriminating them. In total, it is concluded that these results show a better specification of the external model and statistically significant relationships with their measurements. So, Table 7 shows the predictive relevance of the latent variables for the measurement model or internal model. It is particularly important to understand the contribution of each explanatory variable to the prediction of the dependent variable and the estimation of the structural model. 


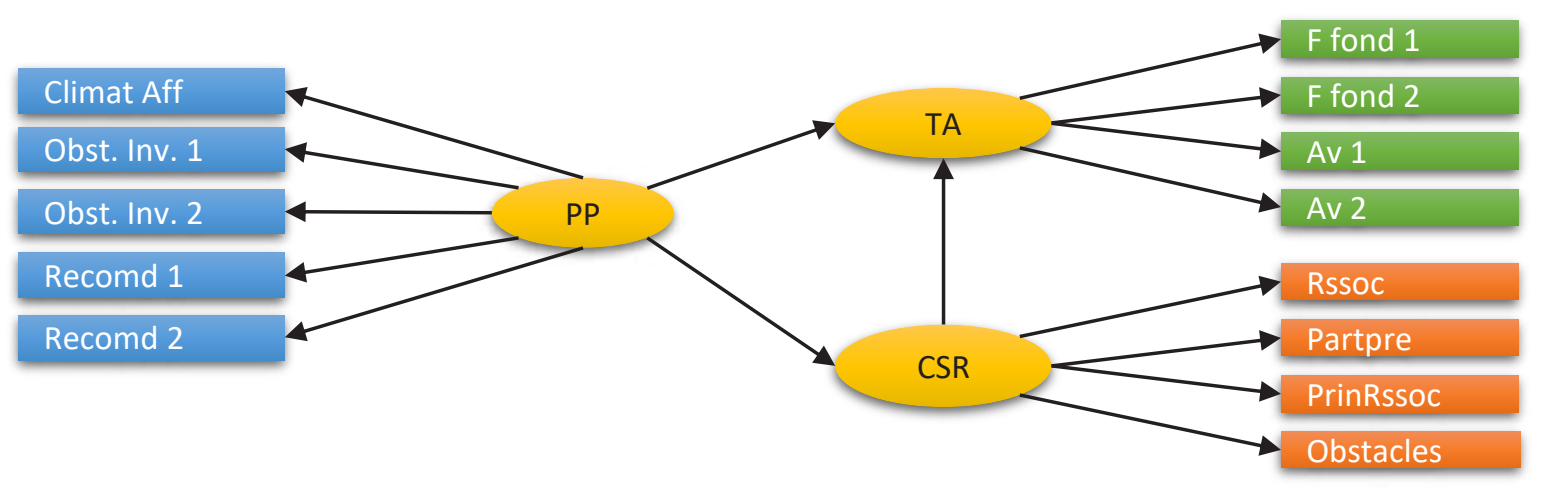

Figure 5. Estimated model

Table 7. Model evaluation

\begin{tabular}{|c|c|c|c|c|c|c|}
\hline $\begin{array}{c}\text { Latent } \\
\text { variable }\end{array}$ & Type & $\begin{array}{c}\text { Moyenne } \\
\text { (variables } \\
\text { manifestes) }\end{array}$ & $R^{2}$ & Adjusted $R^{2}$ & $\begin{array}{c}\text { Communalities } \\
\text { means (AVE) }\end{array}$ & $\begin{array}{c}\text { Redundancy } \\
\text { mean }\end{array}$ \\
\hline APP & Exogeneous & 0.000 & - & - & 0.455 & - \\
\hline RSE & Endogeneous & 0.000 & 0.870 & 0.870 & 0.911 & 0.793 \\
\hline AT & Endogeneous & 0.000 & 0.898 & 0.897 & 0.470 & 0.422 \\
\hline Mean & - & - & 0.884 & - & 0.600 & 0.608 \\
\hline
\end{tabular}

This also means that the variables that reflect $\mathrm{PP}$ to improve the CSR practices and the variables that reflect the CSR account for a large part of the attraction of FDI.

The measurement models use the components obtained with the PCA.

Figure 5 illustrates the estimated conceptual model.

\subsubsection{Assessment of the fit quality of the global model}

The quality of the overall model is checked using the index GoF for the case of both models (internal and external). That is, the quality of the fit in each relationship of the model. These relations reflect the dynamics of the impact of the exogenous concepts between them and to study the direct and indirect effects that these concepts can exert on the TA. For the of fit of the model, Table 8 shows that the GoF (Goodness of Fit) of the two internal and external models is very high (0.944), which reflects a good quality of adjustment of the model to the empirical data.
Table 8. Model's linear quality

\begin{tabular}{l|c|c|c}
\hline & GoF & $\begin{array}{c}\text { GoF } \\
\text { (Bootstrap) }\end{array}$ & $\begin{array}{c}\text { Critical } \\
\text { ratio (CR) }\end{array}$ \\
\hline Absolute & 0.728 & 0.723 & 15.226 \\
\hline Relative & 0.944 & 0.930 & 17.735 \\
\hdashline External model & 0.990 & 0.976 & 19.964 \\
\hline \begin{tabular}{l} 
Internal model \\
\hline
\end{tabular} & 0.953 & 0.953 & 103.361 \\
\hline
\end{tabular}

\section{RESULTS ANALYSIS}

It involves the analysis of the relationship between the three basic concepts and the validation or rejection of the three main hypotheses.

\subsection{Effect of PP on the attraction of FDI}

Table 9 shows that the value of $t$-stat for the APP (PP) variable is $t=3.827$, with $p<0.001$. Thus, this variable has a significant positive impact on the attraction of FDI.

We can conclude that the PP have a direct impact on the attraction of FDI. PP, such as improving 
Table 9. Direct impact of PP on TA

\begin{tabular}{c|c|c|c|c|c}
\hline $\boldsymbol{R}^{\mathbf{2}}$ & $\boldsymbol{F}$ & $\boldsymbol{P}$-value & $\boldsymbol{R}^{\mathbf{2}}$ (Bootstrap) & Standard error & Critical ratio (CR) \\
\hline 0.898 & 329.824 & 0.000 & 0.900 & 0.016 & 55.581 \\
\hline Latent variable & Value & Standard error & $\mathbf{T}$ & P-value & $\mathbf{f}^{2}$ \\
\hline APP (PP) & 0.392 & 0.102 & 3.827 & 0.000 & 0.195 \\
\hline
\end{tabular}

political stability through the protection of industrial and intellectual property rights of foreign investors, the development of human capital, the improvement of the quality of infrastructures, will be undeniable factors in enhancing the attractiveness of the Tunisian territory. This can be confirmed by several works (Kolstad \& Tondel, 2002; Basu \& Srinivasan, 2002; Méon \& Sekkat, 2007; Karray \& Toumi, 2007; Sfar \& Mtar, 2015), which highlight political stability as a fundamental determinant of the attraction of FDI. They have proved that the political stability is the key to development, because it affects all aspects of community security, which strengthens the attraction of FDI. The protection of the industrial and intellectual property rights of foreign investors is an interesting alternative that will allow the government to foster a stable political climate that will influence the willingness of companies to feel confident and thus invest in new or existing projects (World Bank, 2005; Erb et al., 2000).

In the Tunisian case, in 2014, a strategic study entitled "Étude Stratégique du Système de Propriété Industrielle en Tunisie" was carried out by GIZ (2010) under the mandate of the European Union and the German Federal Ministry for Economic Cooperation and Development (BMZ) in the framework of the research and innovation system support project (PASRI) and in partnership with the Ministry of Industry and the INNORPI (National Institute of Standardization and Property). The main objective of this study is to define a strategy and identify an action plan to support the industrial property system, in particular trademarks and patents, thus, becoming a catalyst and a driving force for the development of the economy in Tunisia. The study revealed several structural deficiencies. The first structural factor is the nature of the Tunisian industrial framework, which limits the expansion of industrial property. Indeed, there are not enough innovations in Tunisia to claim the development of industrial property. The second structural factor, revealed by this study, concerns the collaboration between researchers and companies that does not really work, a framework that encounters difficulties to put in place heavy administrative procedures, unmotivated researchers, objectives and discordant cultures between researchers and companies. The study highlighted other obstacles, such as the lack of a real job as a coach and intellectual property advisor, which hampered the development of industrial property.

This hypothesis is also adapted to the empirical work's of Borensztein et al. (1998), Lucas (1988), Andreosso (2002), Aghion and Cohen (2004), Goumrhar (2017), which showed that the development of human capital is a fundamental element that promotes the attraction of FDI in the host countries. Finally, this hypothesis is supported by the empirical study of Saidi and Hammami (2014), which revealed that Tunisia followed for several years a strategy of attractiveness based on the quality of the workforce. Indeed, this country has increased the number of vocational training centers in all activities, especially those required by multinationals to improve its attractiveness. In addition, the enrollment rate in higher education has increased. As a result, skilled human capital has improved Tunisia's competitiveness and attractiveness in terms of FDI. This study also confirmed that the internationalization of companies has favored the establishment of a high value-added transport system capable of meeting the demand of companies. Thus, the authors concluded that the existence of this good logistics has positively influenced the entry of FDI into Tunisia. The first hypothesis that PP have a direct impact on the attraction of FDI is thus confirmed.

\subsection{Effect of PP on CSR practices}

Table 10 presents the effect of PP on the improvement of CSR practices. According to this table, the value of $t$-stat for the PP variable is $t=22.569$, with $p<0.001$. Thus, this variable has a significant positive effect on improving CSR practices. 
Table 10. Effect of PP on CSR practices

\begin{tabular}{c|c:c:c:c}
\hline $\boldsymbol{R}^{2}$ & $\mathbf{F}$ & $\mathbf{P}$ & $\begin{array}{c}\boldsymbol{R}^{2} \\
\text { (Bootstrap) }\end{array}$ & $\begin{array}{c}\text { Critical } \\
\text { ratio (CR) }\end{array}$ \\
\hline 0.870 & 509.382 & 0.000 & 0.872 & 28.148 \\
\hline \multicolumn{4}{c}{ Path coefficients (RSE/1): } \\
\hline $\begin{array}{c}\text { Latent } \\
\text { variable }\end{array}$ & Value & $\begin{array}{c}\text { Standard } \\
\text { error }\end{array}$ & $\boldsymbol{T}$ & $\mathbf{f}^{2}$ \\
\hline APP & 0.933 & 0.041 & 22.569 & 6.702 \\
\hline
\end{tabular}

This confirms the work of Albareda et al. (2007) who tried to analyze a new government approach that can promote CSR in 15 countries of the European Union such as Italy, Spain, Sweden, Luxemburg, France, Germany and Greece. These countries are considered as the countries with the most developed CSR policies. Albareda et al. (2007) attempted to build a database that integrates the policies and instruments applied by each government. Table 11 groups the different models of government actions that promote CSR in these 15 countries.

Table 11. Models of policies improving CSR practices in $15 \mathrm{EU}$ countries

Source: According to Albareda et al. (2007)

\begin{tabular}{|c|c|c|}
\hline Model & Characteristics & Countries \\
\hline Partnership & $\begin{array}{l}\text { Partnership as strategy shared } \\
\text { between sectors for meeting } \\
\text { socio-employment challenges }\end{array}$ & $\begin{array}{l}\text { Denmark, } \\
\text { Finland, the } \\
\text { Netherlands }\end{array}$ \\
\hline $\begin{array}{l}\text { Sweden } \\
\text { (business in } \\
\text { the Kingdom } \\
\text { community) }\end{array}$ & $\begin{array}{l}\text { Soft intervention policies } \\
\text { to encourage company } \\
\text { involvement in governance } \\
\text { challenges affecting the } \\
\text { community (entrepreneurship } \\
\text { and voluntary service) }\end{array}$ & $\begin{array}{l}\text { Ireland, the } \\
\text { United } \\
\text { Germany, } \\
\text { Austria }\end{array}$ \\
\hline $\begin{array}{l}\text { Sustainability } \\
\text { and } \\
\text { citizenship } \\
\text { (Belgium) }\end{array}$ & $\begin{array}{l}\text { Updated version of the } \\
\text { existing social agreement } \\
\text { and emphasis on a strategy } \\
\text { of sustainable development } \\
\text { regulatory }\end{array}$ & $\begin{array}{l}\text { Luxembourg, } \\
\text { France }\end{array}$ \\
\hline $\begin{array}{l}\text { Agora } \\
\text { (Greece) }\end{array}$ & $\begin{array}{l}\text { Creation of discussion groups } \\
\text { for the different social actors } \\
\text { to achieve public consensus } \\
\text { on CSR }\end{array}$ & $\begin{array}{l}\text { Italy, Spain, } \\
\text { Portugal }\end{array}$ \\
\hline
\end{tabular}

These results are also supported by the empirical work of Doh and Guay (2006), which explained the differences in NGO strategies and the power in the European Union compared to the United States. It concluded that NGOs are more influential in the European Union. This is explained by the process of government policy-making marked by the existence of clear and explicit pathways that include the views of business and civil society, which is not the case for the United States, which is characterized by more liberal and individualistic tendencies of political thought.

In the Tunisian case, a social contract was signed in 2014 by the three social partners, the Tunisian government, the Tunisian General Labor Union and the Tunisian Union of Industry and Commerce, considering the objectives of the revolution of January 14, 2011 and the Tunisian people's desire to build a civil and democratic republic based on the guarantee of individual and collective freedoms and the fight against poverty (International Labor Organization, 2017).

In the same year, the Tunisian government set up the national reference framework for governance. Its objective is to set up a governance system based on economic and human development in order to promote investment and regional attractiveness. This repository defines the values that will promote the ethical commitment of organizations (National Institute of Standardization and Property, 2016).

The second hypothesis that PP have a significant positive impact on CSR practices is thus confirmed.

\subsection{Effect of improving CSR practices on the attraction of FDI}

Table 12 illustrates the effect of improving CSR practices by $\mathrm{PP}$ on the attraction of FDI. It shows that the statistic of the CSR practices variable is $t=5.582$, with $p<0.001$. Thus, this variable has a significant positive effect on the attraction of FDI.

This confirms the work of Cavalcanti et al. (2008) and Acemoglu et al. (2010), who have shown that institutional reforms have a significant positive impact on the attraction of FDI. The results of this hypothesis are also consistent with Easterly's (2005) study, which confirmed that property rights, the rule of law, trust between individuals,

Table 12. Effect of improving CSR practices on the attraction of FDI

\begin{tabular}{c|c|c|c|c|c}
\hline $\boldsymbol{R}^{\mathbf{2}}$ & $\boldsymbol{F}$ & $\boldsymbol{P r}>\boldsymbol{F}$ & $\boldsymbol{R}^{\mathbf{2}}$ (Bootstrap) & Standard error & Critical ratio (CR) \\
\hline 0.898 & 329.824 & 0.000 & 0.900 & 0.016 & 55.581 \\
\hline Latent variable & Value & Standard error & $\mathbf{T}$ & $\mathbf{P r}>\boldsymbol{l t}^{\mathbf{2}}$ & $\boldsymbol{f}^{2}$ \\
\hline RSE (CSR) & 0.572 & 0.102 & 5.582 & 0.000 & 0.415 \\
\hline
\end{tabular}


the credibility of government, and respect for human rights have an "attractor" role for FDI. This hypothesis can also be supported by the study of Wei (2000) who found that in most countries in Sub-Saharan Africa, high levels of corruption can complicate business operations and increase uncertainty for investors.

In the field of infrastructures, Tunisia has made many efforts to rethink the quality of port services in Tunisia; indeed, the transport sector remains the most attractive point for foreign investors. Among the actions put in place by the Tunisian government:

a. Facilitating the flow of information flows by improving services in ports, airports:

In this context, the Tunisian government has promoted the use of ICT (new information and communication technologies). A strategy for optimizing and improving services at the port of Rades has been put in place to facilitate the exchange of information between Tunisian customs, STAM and other public offices (European Bank for Reconstruction and Development, 2016).

Some actions of the implementation of this strategy quoted in the report of the European Bank for Reconstruction and Development such as strengthening safety and security in the commercial port of "Rades" and the establishment of a system of control and registration of the access of persons to the port of "Rades".

Table 13. PEST analysis b. The valorization of a participative approach, which is a key factor of transmission of information in different fields:

An agreement was signed between the Republic of Tunisia and the International Bank for Reconstruction and Development to finance the third project of Export Development Project (III). This project is a good example of a participatory approach that will allow the flow of information between the various actors in Tunisia (Ministry of Industry, Customs, Ministry of Transport, and Center for the Promotion of Exports in Tunisia). (Ministry of Commerce, 2016).

Finally, this hypothesis adapts to the study carried out by Martinet and Payaud (2010) who concluded the importance of the financial incentives offered by the government to develop a global strategy for sustainable development. In this regard, Tunisia's new investment law aims to increase the competitiveness and export capacity of the country's national economy. With reference to this law, investments in pollution control and environmental protection projects benefit from a sustainable development bonus of $50 \%$ of the value of the approved investment components with a ceiling of 300 thousand dinars (Investment law of Tunisia,2018).

The third hypothesis that the improvement of CSR practices through the PP has a significant positive impact on the attraction of (FDI), is thus confirmed.

Source: El Malki (2010), Navas and Guerras (2018).

\begin{tabular}{|c|c|c|c|}
\hline \multicolumn{2}{|c|}{ Political dimension } & \multicolumn{2}{|c|}{ Economic dimension } \\
\hline Opportunities & Threats & Opportunities & Threats \\
\hline $\begin{array}{l}\text { Governance is a process } \\
\text { that helps to strengthen } \\
\text { democracy and human rights } \\
\text { Harmonization and } \\
\text { simplification of taxation } \\
\text { favor the efficiency of the tax } \\
\text { system }\end{array}$ & $\begin{array}{l}\text { Some restrictions constitute } \\
\text { obstacles to foreign trade } \\
\text { Corruption is one of the biggest } \\
\text { constraints on the operation of } \\
\text { public administrations }\end{array}$ & $\begin{array}{l}\text { The development of financial } \\
\text { market is essential, because } \\
\text { it helps to reduce poverty by } \\
\text { reducing income inequalities }\end{array}$ & $\begin{array}{l}\text { Information asymmetry at the } \\
\text { level of banks and lenders in } \\
\text { general is a factor that can } \\
\text { restrict the well-functioning of } \\
\text { the financial market }\end{array}$ \\
\hline
\end{tabular}
system

Socio-cultural dimension

\begin{tabular}{|c|c|c|c|}
\hline Opportunities & Threats & Opportunities & Threats \\
\hline $\begin{array}{l}\text { The establishment of a } \\
\text { dialogue between labor } \\
\text { unions and managers } \\
\text { improves the flow of } \\
\text { information }\end{array}$ & $\begin{array}{l}\text { The existence of a cheap but } \\
\text { unqualified workforce occupies } \\
\text { only a secondary place in the } \\
\text { determinants of investment }\end{array}$ & $\begin{array}{l}\text { Promoting the use of } \\
\text { information systems } \\
\text { maximizes value creation and } \\
\text { is a source of innovation for } \\
\text { the company }\end{array}$ & $\begin{array}{l}\text { Intellectual property is } \\
\text { intangible, so it can be easily } \\
\text { transferred across borders } \\
\text { which causes a problem of } \\
\text { intellectual property rights } \\
\text { protection }\end{array}$ \\
\hline
\end{tabular}




\section{DISCUSSION}

To promote political stability, the authors concluded that good governance helps to strengthen democracy and human rights, to promote prosperity and social cohesion, to reduce poverty, to support the protection of the environment and to strengthen public confidence in the action and administration of the state. In addition, the harmonization and simplification of taxation favor the efficiency of the tax system.

On the economic front, the authors found that the development of the financial market is essential, because it helps to reduce poverty by reducing income inequalities. This will be by facilitating access to finance for people who do not have sufficient economic resources.

Moreover, the authors proved that asymmetric information at the level of banks and lenders in general is liable to restrict the well-functioning of financial market, because they do not have sufficient information about their potential customers. These market imperfections can lead to a blockage of a country's savings that results in the inability to move towards structuring investment projects.

On the social level, the existence of a cheap but unqualified workforce occupies only a secondary place in the determinants of investment. Indeed, multinationals are looking for a high-quality workforce as these companies are interested in the production of capital-intensive goods and technology. In the same context, the authors emphasized the importance of establishing a dialogue between the unions and the managers of the firms, which improves the flow of information and enhances social cohesion.

Finally, in terms of technology, the authors concluded that the use of information systems maximizes value creation and is a source of innovation for the company. They also concluded, that the establishment of a good infrastructure makes it possible to link the different agents in a market through the existence of access routes (air, land and sea) and contributes to reducing production costs by to benefit from modern production techniques. So, firms with access to a reliable transportation network and modern telecommunications infrastructure invest more than those that do not have access.

\section{CONCLUSION AND IMPLICATIONS}

The purpose of this study was to present and empirically test a conceptual framework that describes the essential role of PP in improving CSR practices of fully exporting companies, which favors the entry of new foreign investors. This latter provides several contributions. First, the theoretical contribution is to highlight the originality of this study. Indeed, subsequent studies that have been interested in analyzing the relationship between the improvement of CSR practices by PP and TA are limited or non-existent, therefore, this study aims to make a contribution in this direction. Second, the methodological contributions concern the introduction of a survey on the government's commitment in improving CSR practices to attract FDI, by studying the opinions of foreign investors. This is an interpretation of the points of view of these investors by referring to the three basic concepts, namely TA, CSR practices and PP. Third, the operational contribution is the consideration of the role of PP in improving CSR practices as a social fact using a multidisciplinary approach. In this respect, several recommendations can be proposed to the Tunisian government.

The development of the local economic framework of the country, considered as a necessary condition for the attractiveness of FDI, requires the improvement of the quality of basic education. This can be done not only through certification, but also by accreditation systems. Then, it seems useful in this postrevolutionary context to draw up an action plan for a continuing vocational training policy, which will promote the improvement of employee's ability to adapt to structural changes. Additionally, it is necessary to increase financial and fiscal incentives to implement real CSR strategies, such as the granting of financial and fiscal incentives for social, ecological and economic projects, which promotes the entry of FDI. Finally, political stability as a key factor in attracting FDI, must be promoted by the protection 
of intellectual property rights, which will make it more difficult to reproduce elements of intellectual property rights. As a result, companies will be encouraged to put in place long-term investment strategies. It is therefore necessary to value a social consensus in favor of building a more productive society that respects certain common values (sharing, equity, solidarity, etc.).

Although, this research involves several contributions, it has some limits. A first limit is related to theoretical choices concerning the design of the general model of research. It is about the selection of the dimensions of the three basic concepts. This reflects the inability to report to other dimensions that may provide information to our analysis, although the most representative dimensions in this study have been cited in the literature. The second limit is related to the complexity of the concept of TA. It is a multidimensional concept that can be approached in several aspects, which has sometimes hindered the precision of some ideas and affirmations. Finally, this work presents a limit linked to the methodological choices. Therefore, information and results, if they are reliable in the Tunisian context, are not necessarily in the context of other territories. These limits will be investigated in the future researches. In order to build the conceptual model for the Tunisian case, the concepts that characterize the dynamics of operation, as well as the dimensions and the items reflecting each concept, are presented below. These concepts are inspired by the empirical literature and are subject to empirical validation on a sample of foreign subsidiaries located in Tunisia.

\section{REFERENCES}

1. Acemoglu, D., \& Robinson, J. (2008). The Role of Institutions in Growth and Development. World Bank, Washington DC, 1, 1-33. Retrieved from https://siteresources.worldbank.org/EXTPREMNET/Resources/489960-1338997241035/ Growth_Commission_Working_Paper_10_Role_Institutions_ Growth_Development.pdf

2. Aghion, P., \& Cohen, É. (2004). Éducation et croissance. Conseil d'Analyse Économique, La documentation française, Paris.

3. Albareda, L., Lozano, J. M., \& Ysa, T. (2007). Public policies on corporate social responsibility: The role of governments in Europe. Journal of Business Ethics, 74(4), 391-407. Retrieved from https:// link.springer.com/article/10.1007/ s10551-007-9514-1

4. Alesina, A., Devleeschauwer, A., Easterly, W., Kurlat, S., \& Wacziarg, R. (2003). Fractionalization. Journal of Economic Growth, 8(2), 155-194. Retrieved from https:// www.nber.org/papers/w9411

5. Andréosso-O'Callaghan, B. (2002). Human Capital Accumulation and Economic Growth in Asia (National Europe Centre Paper No.
29, p. 1-12). Australian National University. Retrieved from https:// www.researchgate.net/publication/265669536_Human_Capital_Accumulation_and_Economic_Growth_in_Asia

6. Asaftei, G., Kumbhakar, S. C., \& Mantescu, D. (2008). Ownership, business environment and productivity change. Journal of Comparative Economics, 36(3), 498-509. Retrieved from https:// doi.org/10.1016/j.jce.2008.03.005

7. Basu, M. A., \& Srinivasan, M. K. (2002). Foreign direct investment in Africa: Some case studies. International Monetary Fund. Retrieved from https://www.imf. org/external/pubs/ft/wp/2002/ wp0261.pdf

8. Beaujolin-Bellet, R. (2008). Le territoire, laboratoire d'innovations en matière de gestion des conséquences des restructurations. Revue de gestion des ressources humaines, 17-29.

9. Benhamou, S., Diaye, M.-A., \& Crifo, P. (2016). Responsabilité sociale des entreprises et compétitivité. Évaluation et approche stratégique. Revue des Sciences de Gestion, 223, 57-65. Retrieved from https://www.actu-envi- ronnement.com/media/pdf/news26288-france-strategie-rse.pdf_

10. Ben Slymen, S. (2014). Sentiment d'appartenance et intelligence territoriale: une application au contexte tunisien (Doctoral thesis). Nice. Retrieved from http://www.theses. fr/2014NICE2038

11. Bertacchini, Y. (2004). Le territoire, une entreprise d'intelligence collective à organiser vers la formation du capital formel local. Communication et Organisation, 25(25). Retrieved from https:// journals.openedition.org/communicationorganisation/2948

12. Borchani Maktouf, M. (2008). Les déterminants de la stratégie sociétale des firmes multinationales: étude empirique des filiales étrangères en France. Retrieved from http://www.strategie-aims. com/events/conferences/10 xiiieme-conference-de-l-aims/ communications/569-les-determinants-de-la-strategie-societale-des-multinationales-etude-exploratoire-des-entreprises-etrangeres-en-france/download

13. Borensztein, E., De Gregorio, J., \& Lee, J.-W. (1998). How does foreign direct investment affect economic growth? Journal of 
International Economics, 45(1), 115-135. https://doi.org/10.3386/ w5057

14. Boualam, F. (2008). Les institutions et attractivité des IDE. Colloque International Ouverture et émergence en Méditerranée, Rabat. Retrieved from https://www. gate.cnrs.fr/unecaomc08/Communications $\% 20 \mathrm{PDF} /$ Texte $\% 20$ Fatima\%20BOUALAM.pdf

15. Bronisz, U., \& Heijman, W. (2009). The impact of social capital on the regional growth and competitiveness in Poland. Retrieved from https://ageconsearch.umn.edu/ bitstream/57395/2/Bronisz $\% 20$ Urszula\%20cover.pdf

16. Campbell, J. L. (2007). Why would corporations behave in socially responsible ways? An institutional theory of corporate social responsibility. Academy of Management Review. https://doi.org/10.5465/ amr.2007.25275684

17. Capron, M., \& Quairel-Lanoizelée, F. (2004). Mythes et réalités de lentreprise responsable. Paris: La Découverte. Retrieved from https://www.editionsladecouverte. $\mathrm{fr} /$ catalogue/index-Mythes_et_r_ alit_s_de_1_entreprise_responsable-9782707140951.html

18. Carlin, W. J., Schaffer, M. E., \& Seabright, P. (2006). Where are the Real Bottlenecks? A Lagrangian Approach to Identifying Constraints on Growth from Subjective Survey Data (Centre for Economic Reform and Transition: Discussion Paper 2006/04). Retrieved from https://pdfs. semanticscholar.org/47f2/f59cd7a30c2876a378a8c8e07e5866a52c16. pdf

19. Colletis, G., \& Pecqueur, B. (2005). Révélation de ressources spécifiques et coordination située. Économie et institutions, 6-7, 5174. Retrieved from https://journals.openedition.org/ei/900

20. Cournac, A. (2013). La responsabilité sociale de l'entreprise multinationale à l'égard de ses territoires d'implantation (Doctoral thesis). Pau. Retrieved from https://tel. archives-ouvertes.fr/tel-00924014/ document
21. Creswell, J. W. (2011). Controversies in mixed methods research. In N. K. Denzin \& Y. S. Lincoln (Eds.), The Sage handbook of qualitative research (4th ed.) (pp. 269284). Thousand Oaks, CA: Sage Publications, Inc. Retrieved from https://www.sagepub.com/sites/ default/files/upm-binaries/40426_ Chapter15.pdf

22. Demirgüç-Kunt, A., \& Maksimovic, V. (1998). Law, Finance, and Firm Growth. The Journal of Finance, 53(6), 2107-2137. https:// doi.org/10.1111/0022-1082.00084

23. Doh, J. P., \& Guay, T. R. (2006). Corporate social responsibility, public policy, and NGO activism in Europe and the United States: An institutional-stakeholder perspective. Journal of Management Studies, 43(1), 47-73. https://doi.org/10.1111/j.14676486.2006.00582.x

24. Drabek, Z., \& Payne, W. (2002). The Impact of Transparency on Foreign Direct Investment. Journal of Economic Integration, 17(4), 777-810. Retrieved from https://www.e-jei.org/ upload/148HEKXL3092R4YH.pdf

25. Easterly, W. (2005). National policies and economic growth: a reappraisal. Handbook of Economic Growth, 1(05), 1015-1059. Retrieved from https://papers.ssrn. com/sol3/papers.cfm?abstract $\mathrm{id}=507402$

26. Elhasbi, A., Barkaoui, M., \& Bouksour, O. (2015). The Territorial Attractiveness, Governance, Infrastructures and Logistics Activities: Case of Tangier City, Morocco. Asian Journal of Management Research, 5(3), 438-50. Retrieved from https://www.researchgate. net/publication/289756928_The_ territorial_attractiveness_governance_Infrastructures_and_logistics_activities_Case_of_Tangier_ city_Morocco

27. El Malki, T. (2010). Environnement des entreprises, responsabilité sociale et performance: analyse empirique dans le cas $d u$ Maroc (Doctoral thesis). Aix Marseille 2. Retrieved from http:// www.theses.fr/2010AIX24022
28. Engelschalk, M., Melhem, S., \& Weist, D. (2000). Computerizing Tax and Customs Administrations. Retrieved from https://openknowledge.worldbank.org/bitstream/ handle/10986/11419/multi_page. pdf? sequence $=1$ \&isAllowed $=y$

29. Erb, C. B., Harvey, C. R., \& Viskanta, T. E. (2000). The Risk and Expected Returns of African Equity Investment. In Investment and Risk in Africa (pp. 122-150). Palgrave Macmillan UK.

30. European Bank for Reconstruction and Development (2016). Plan d'amélioration de la compétitivité des services (Rapport final). Colombus Consulting. Retrieved from https://fr.slideshare.net/ MondherKhanfir/plan-damlioration-de-la-comptitiivit-du-secteurtransport-logistique-en-tunisie

31. Fafchamps, M. (2004). Market Institutions in Sub-Saharan Africa: Theory and Evidence (Vol. 1). The MIT Press. Retrieved from https:// mitpress.mit.edu/books/marketinstitutions-sub-saharan-africa

32. Goumrhar, H. (2017). Human capital, Inequality and Economic Growth in developing Countries: Analysis in Panel Data. International Journal of Innovation and Applied Studies, 20(2), 441-460. Retrieved from http://www. ijias.issr-journals.org/abstract. php?article=IJIAS-16-332-01

33. Hatem, F. (2004). Investissement international et politiques d'attractivité. Paris: Economica. Retrieved from https://books.google. com.ua/books/about/Investissement_international_et_politiqu. html?id=AIuxAAAAIAAJ\&redir esc $=\mathrm{y}$

34. Houle, E. (2012). La responsabilité sociale des entreprises dans les pays en développement avec des problèmes de gouvernance. Université de Sherbrooke. Retrieved from https://www.usherbrooke.ca/environnement/fileadmin/sites/environnement/documents/Essais2011/ Houle_E_09-01-2012_.pdf

35. Igalens, J., Joras, M., \& Mancy, F. (2002). La responsabilité sociale de lentreprise: comprendre, rédiger le rapport annuel. Editions d'Organisation. 
36. Igalens, J., \& Vicens, C. (2005). Vers des restructurations socialement responsables? Management \& Avenir, 3(1), 101. Retrieved from https://www.cairn.info/ revue-management-et-avenir2005-1-page-101.htm

37. International Labor Organization (2017). Le contrat social un exemple innovant de programme par pays pour le travail décent (PPTD) pour la Tunisie. Tunisie. Retrieved from https://www.ilo.org/wcmsp5/ groups/public/---ed_mas/--program/documents/genericdocument/wcms_568657.pdf

38. Ministry of Industry, Tunisia (2018). Investment law of Tunisia. Retrieved from http://www.legislation.tn/sites/default/files/codes/ investissement.pdf

39. Joffre, P., \& Koenig, G. (1992). Gestion stratégique: l'entreprise, ses partenaires-adversaires et leur univers. Litec.

40. Karray, Z., \& Toumi, S. (2007) Investissement Direct Étranger et Attractivité Appréciation et enjeux pour la Tunisie. Revue d'Économie Régionale et Urbaine, 3, 479-501. Retrieved from https://www.cairn. info/revue-d-economie-regionaleet-urbaine-2007-3-page-479.htm

41. Kolstad, I., \& Tøndel, L. (2002). Social development and foreign direct investments in developing countries. Chr. Michelsen Institute.

42. Kübler, D. (2001). On the regulation of social norms. Journal of Law, Economics, and Organization, 17(2), 449-476. Retrieved from https://www.jstor.org/ stable/3554935?seq=1\#page_scan_ tab_contents

43. La Deutsche Gesellschaft für Internationale Zusammenarbeit (GIZ) (2010). La Responsabilité Sociétale des entreprises (RSE) en Tunisie, Etat des lieux. Afrique du sud.

44. La Deutsche Gesellschaft für Internationale Zusammenarbeit (GIZ) (2014). Etude Stratégique du Système de Propriété Industrielle. Tunisia.

45. La Porta, R. R., Lopez-de-Silanes, F., Shleifer, A., Vishny, R. W., \& Vishney, R. (1999). The Quality of
Government. Journal of Law, Economics, and Organization, 15(1), 222-279. Retrieved from https:// scholar.harvard.edu/shleifer/publications/quality-government

46. Le Roy, A., \& Ottaviani, F. (2011). Développer De Nouveaux Indicateurs De Richesse Afin de repenser l'attractivite territoriale? In Colloque interdisciplinaire Aménagement - Economie - Droit - Géographie - Sociologie - Statistiques (pp. 23-24).

47. Leriche, F., Daviet, S., SibertinBlanc, M., \& Zuliani, J. M. (2006). Léconomie culturelle et ses territoires: quels enjeux? In Léconomie culturelle et ses territoires. Presses Universitaires du Mirail. Retrieved from https:// halshs.archives-ouvertes.fr/ halshs-00286485/document

48. Lucas, R. E. (1988). On the mechanics of economic development. Journal of Monetary Economics, 22(1), 3-42. https://doi. org/10.1016/0304-3932(88)901687

49. Martinet, A.-C., \& Payaud, M. A. (2008). Le développement durable, vecteur et produit d'une régénération de la gouvernance et du management stratégique: Un cadre théorique intégrateur. Management International, 12(2), 12-25. Retrieved from https://www.researchgate.net/ publication/281660014_Le_developpement_durable_vecteur_et_ produit_d'une_regeneration_de_ la_gouvernance_et_du_management_strategique_Un_cadre_theorique_integrateur

50. McWilliams, A., \& Siegel, D. S. (2001). Corporate social responsibility: A theory of the firm perspective. Academy of Management Review, 26(1), 117-127. Retrieved from https://www.jstor.org/ stable $/ 259398$ ?seq $=1$ \#metadata info_tab_contents

51. Méon, P. G., \& Sekkat, K. (2007) Revisiting the relationship between governance and foreign direct investment. Brussels Economic Review, ULB-University Libre de Bruxelles, 50(1), 41-61. Retrieved from https://ideas.repec.org/p/dul/ wpaper/07-13rs.html
52. Michalet, C. A. (1999). La séduction des nations, ou, Comment attirer les investissements. Economica. Retrieved from https:// www.eyrolles.com/Entreprise/ Livre/la-seduction-des-nations-9782717839241

53. Ministry of commerce. (2016). 3ème Projet de Développement des Exportations (PDE III). République Tunisienne. Retrieved from http://www.commerce.gov.tn/Fr/ image.php?id=490

54. Ministry of Industry (2014). Strategic Study of the Industrial Property System in Tunisia.

55. Mkaouar, N. (2016). Impact des caractéristiques de la publicité sur le comportement d'approche/Evitement, le rôle de l'empowerment psychologique de consommateur (Doctoral thesis).

56. Mucchielli, J. L. (1998). Multinationales et mondialisation (Vol. 41). Éd du Seuil.

57. National Institute of Standardization and Property (2016). Référentiel National de la Gouvernance, Tunisie.

58. Navas López, J. E., \& Guerras Martin, L. A. (2018). Fundamentals of strategic management (2nd ed.). Retrieved from http://www. guerrasynavas.com/fsm_presentation.htm

59. Nunnally, J. C., \& Bernstein, I. H. (1979). Psychometric theory. Psyc CRITIQUES, 24, 275-280. https:// doi.org/10.1037/018882

60. OCDE (2003). Perspectives d'Investissement International: Principes directeurs pour les stratégies destinées à attirer l'investissement direct étranger. Paris. Retrieved from http://www. oecd.org/fr/daf/inv/politiquesinvestissement/37472103.pdf

61. Ouguenoune, H. (2014). La politique de promotion et d'attraction de l'investissement en Algérie (Doctoral thesis) Paris 3. Retrieved from https://tel.archives-ouvertes. fr/tel-01172734/document

62. Perret, C. (2011). Capital social et développement territorial (Notes de Recherches, 11-01, IREGE). Université de Savoie. Retrieved from http://hal.univ-grenoblealpes.fr/hal-00980977/document 
63. Pesqueux, Y. (2009). La responsabilité sociale de l'entreprise: un dialogue sans interlocuteur? Vie sociale, 3, 137-154. Retrieved from https://www.cairn.info/revue-viesociale-2009-3-page-137.htm

64. Pleskovic, B., \& Stern, N. (Eds.) (2001). Annual World Bank Conference on development Economics 2000. The World Bank. Retrieved from http://documents.worldbank.org/curated/ en/525851468740663147/AnnualWorld-Bank-Conference-ondevelopment-economics-2000

65. Porter, M. (1986). Comment devancer Lavantage concurrentiel ses concurrents et maintenir son avance. Inter Éditions, Paris.

66. Pumain, D., Thisse, J. F., Thomas, I., \& Walliser, B. (2007). Nouvelle économie géographique et géographie: quel dialogue? L'Espace géographique, 36(3), 193. Retrieved from https://www.cairn. info/revue-espace-geographique2007-3-page-193.htm

67. Rouissi, C. (2017). La perception de la fonction de préférences des stakeholders et les stratégies bancaires: Cas des banques en Tunisie (Doctoral thesis).
68. Saidi, S., \& Hammami, S. (2014). The interaction between transportation, foreign investment and human capital: A new determinant of economic growth in developing countries (The case of Tunisia). International Journal of Economics, Commerce and Management, 2(11). Retrieved from http://ijecm.co.uk/wp-content/ uploads/2014/11/21158.pdf

69. Sfar, S. B. E., \& Mtar, K. (2015) The Determinants of FDI in Tunisia: An Empirical Study through a Gravity Model. Asian Economic and Financial Review, 5(12), 3061314. Retrieved from http://www. aessweb.com/pdf-files/aefr-20155(12)-1306-1314.pdf

70. Tang, Y., Ma, Y., Wong, C. W. Y., \& Miao, X. (2018). Evolution of government policies on guiding corporate social responsibility in China. Sustainability (Switzerland), 10(3). https://doi.org/10.3390/ su10030741

71. Thiétart, R.-A. (2003). Méthodes de recherche en management. In Thietart RA et coll Dunod (p. 537). 3ème éditi. Retrieved from https:// www.dunod.com/sites/default/ files/atoms/files/9782100711093/ Feuilletage.pdf
72. United Nations Industrial Development Organization (UNIDO) (2016). RAPPORT ANNUEL, Vienne. Retrieved from https://www.unido.org/sites/ default/files/2017-04/Annual_Report_2016_-_EN_0.pdf

73. Vilatte, J. C. (2007). Méthodologie de l'enquête par questionnaire. Laboratoire Culture et Communication, Université d'Avignon.

74. Wei, S. J. (2000). How taxing is corruption on international investors? Review of Economics and Statistics, 82(1), 1-11. https://doi. org/10.1162/003465300558533

75. World Bank (2005). A better Investment climate for everyone (World Development Report, Washington). Retrieved from http://siteresources.worldbank. org/INTWDR2005/Resources/ complete_report.pdf

76. Word Bank (2015). Tunisie, Diagnostic-pays systématique, Moyen-Orient et Afrique du nord. Retrieved from http:// documents.worldbank.org/curated/en/687071467997282070/ pdf/102298-FRENCHSCD-P151647-PUBLICBox394833B-TUNISIA-SCDpublication.pdf 


\section{APPENDIX A}

Table A1. Conceptualization of variables

\begin{tabular}{|c|c|}
\hline \multicolumn{2}{|r|}{ Dimensions of territorial attractiveness (TA) } \\
\hline Dimensions & Items \\
\hline $\begin{array}{l}\text { Fundamental factors of } \\
\text { territorial attractiveness } \\
\text { (F fond) }\end{array}$ & $\begin{array}{l}\text { - the political climate is a determining factor of territorial attractiveness; } \\
\text { - the macroeconomic climate is a determining factor of territorial attractiveness; } \\
\text { - the legislation and the judicial system is a determining factor of territorial attractiveness; } \\
\text { - the market size is a determining factor of territorial attractiveness; } \\
\text { - the workforce is a determining factor of territorial attractiveness }\end{array}$ \\
\hline $\begin{array}{l}\text { Conditions necessary } \\
\text { for attractiveness (Av) }\end{array}$ & $\begin{array}{l}\text { - the geographical situation is a specific advantage of the place of investment; } \\
\text { - the existence of business relationships is a distinct advantage of the place of investment; } \\
\text { - the low cost of production and the existence of incentives is a distinct advantage of the place of } \\
\text { investment; } \\
\text { - geographical and cultural considerations is a distinct advantage of the place of investment; }\end{array}$ \\
\hline \multicolumn{2}{|r|}{ Dimensions of Corporate Social Responsibility (CSR) } \\
\hline Dimensions & Items \\
\hline $\begin{array}{l}\text { Determinants of the } \\
\text { social strategy of the } \\
\text { subsidiary (Rssoc) }\end{array}$ & $\begin{array}{l}\text { - the activity sector of the subsidiary is a factor that influences the company's social strategy; } \\
\text { - the size of the subsidiary is a factor that influences the company's social strategy; } \\
\text { - the beliefs of the manager is a factor that influences the company's social strategy; } \\
\text { - legislation and social standards are factors that influence the company's social strategy; } \\
\text { - group pressure is a factor that influences the company's social strategy }\end{array}$ \\
\hline Stakeholders (Partpre) & $\begin{array}{l}\text { - the employees is an important category of players in defining the company's social strategy; } \\
\text { - the creditors is an important category of players in defining the company's social strategy; } \\
\text { - the public authorities is an important category of actors in the definition of the company's social } \\
\text { - the local communities is an important stakeholder category in defining the company's social strategy; } \\
\text { the civil society associations, non-governmental organizations) is an important category of actors in } \\
\text { the definition of the company's social strategy; } \\
\text { the business partners is an important category of players in the definition of the company's social } \\
\text { strategy; } \\
\text { the international community is an important category of actors in the definition of the company's } \\
\text { social strategy }\end{array}$ \\
\hline $\begin{array}{l}\text { Principles of CSR } \\
\text { (PrinRssoc) }\end{array}$ & $\begin{array}{l}\text { - it is important to create wealth in the professional world; } \\
\text { - it is important to respect laws and regulations in the professional world; } \\
\text { - it is important to value the human side in the professional world; } \\
\text { - it is important to provide complete information in the professional world; } \\
\text { - it is important to produce ecologically in the professional world }\end{array}$ \\
\hline $\begin{array}{l}\text { Obstacles to overcome } \\
\text { in the implementation } \\
\text { of a social } \\
\text { responsibility policy } \\
\text { (Obstacles) }\end{array}$ & $\begin{array}{l}\text { - the market restrictions have been an obstacle to overcome in defining your company's social strategy; } \\
\text { the uncertainty about the legal scope of CSR has been an obstacle to overcome in defining your } \\
\text { company's social strategy; } \\
\text { the lack of information on CSR has been an obstacle to overcome in the implementation of the } \\
\text { company's social strategy; } \\
\text { the stakeholder involvement has been an obstacle to overcome in implementing the company's social } \\
\text { strategy; } \\
\text { the choice of partner associations for the CSR approach has been an obstacle to overcome in } \\
\text { implementing the company's social strategy }\end{array}$ \\
\hline \multicolumn{2}{|r|}{ Dimensions of the improvement of social practices by the state (PP) } \\
\hline Dimensions & Items \\
\hline $\begin{array}{l}\text { Investment climate } \\
\text { improvements (Climat } \\
\text { Aff) }\end{array}$ & $\begin{array}{l}\text { - the investment climate in Tunisia is characterized by the protection of property rights; } \\
\text { - the investment climate in Tunisia is characterized by the transparency of the legislative and regulatory } \\
\text { framework; } \\
\text { - the investment climate in Tunisia is characterized by the development of human capital; } \\
\text { - the investment climate in Tunisia is characterized by modern technological infrastructures; } \\
\text { the investment climate in Tunisia is characterized by the good reputation of public institutions }\end{array}$ \\
\hline $\begin{array}{l}\text { Obstacles that prevent } \\
\text { foreign investors from } \\
\text { investing (Obst.Inv) }\end{array}$ & $\begin{array}{l}\text { - the corruption in the customs and tax administration is a barrier that prevents investors from investing; } \\
\text { - the violation of human rights is an obstacle that prevents investors from investing; } \\
\text { - the administrative slowness is a barrier that prevents foreign; } \\
\text { - insufficient skilled labor is a barrier that prevents foreign investors from investing; }\end{array}$ \\
\hline $\begin{array}{l}\text { Recommendations } \\
\text { proposed to the state } \\
\text { (Recomd) }\end{array}$ & $\begin{array}{l}\text { - fighting corruption in government can encourage foreign investors to invest in Tunisia; } \\
\text { - the protection of intellectual property rights can encourage foreign investors to invest in Tunisia; } \\
\text { - the introduction of flexible labor policies may encourage foreign investors to invest in Tunisia; } \\
\text { - improving the flow of information may encourage foreign investors to invest in Tunisia; } \\
\text { - promoting Tunisia's brand image can encourage foreign investors to invest in Tunisia }\end{array}$ \\
\hline
\end{tabular}

